Throughout the discussion reference was frequently made to the need for the precise definition of terms, particularly the term 'truth' in the expression that 'science is concerned with the search for truth'. As one speaker aptly expressed the problem in reference to X-rays : Which is to be regarded as truth, $(a)$ the fact that we can measure the wave-length of X-rays, or $(b)$ the fact that we can use $\mathrm{X}$-rays for therapeutic purposes? Again in regard to chloroform, $(a)$ we know the chemical structure of the substance, and (b) we can employ it in order to alleviate pain. In each case are not the two aspects of our knowledge intimately bound together? This speaker concluded that we are unable to insist on the freedom of pure science.

From what has been said above, it will be clear that Dr. Baker opened up an important subject for consideration in war-time when everyone is deeply concerned with what we are to do with our lives both as individuals and as members of the community. His problems are of more than mere academical interest, and an outside observer at the discussion could not fail to be impressed with the sincere desire of the many scientific workers present to make their due contribution, in whatever form may be most appropriate, to the best needs of the community.

\section{THE MALACOLOGICAL SOCIETY OF LONDON, 1893-1943}

$\mathrm{O}$ N February 27, 1893, W. H. Hudleston, F.R.S., then president of the Geological Society, presided over a meeting at which the Malacological Society of London was inaugurated and the first council elected with Dr. Henry Woodward, F.R.S., as first president. On February 27 last the Society commemorated its jubilee in the rooms of the Linnean Society at its 415th meeting, with the twentieth president, Dr. A. T. Hopwood, in the chair.

Of the original seventy members Mr. E. R. Sykes (president 1904-7) and $\mathrm{Mr}$. J. R. le B. Tomlin. (president 1916-19) sent greetings, and Mr. A. S. Kennard (president 1922-25) gave an account of the Society's early history. Founded for the study of Mollusca, it owed much of its success to the enthusiasm of its first secretary, E. R. Sykes, and to the assistance of E. A. Smith, who was in charge of the British Museum Mollusca from 1871 until 1913. The Society early attracted notice in other countries and among the fifty-one corresponding members of its first year were included: W. H. Dall (1845-1927), who studied under Agassiz; C. Hedley (1862-1926), R. Tate (1840-1901), Joseph C. Verco (1851-1933), in Australia ; F. W. Hutton (1836-1905), H. Suter (18411918) in New Zealand ; H. C. Burnup (1852-I928), of the Natal Museum; Ph. Dautzenberg (1849-1935), of Paris, and the Marchese di Monterosato (1841--1927), of Palermo, two of the greatest private collectors; P. Fischer (1835-1893), best known of that family of many malacologists ; M. Cossmann (1850-1924), who despite the heavy duties of chief technical officer of the Chemin de fer du Nord wrote a revision of the Paris Basin mollusca; A. Brot (1821-1896), of Geneva ; S. Brusina (1845-1898), of Agram University; W. Kobelt (1840-1916); E. von Martens (1831-1904), first, and for twenty-one years, recorder of the molluscan section of the Zoological Record. The keen interest of H. A. Pilsbry, elected in 1894, brought in more American members, including C. W. Johnson (1863-1932), co-editor with him of the Nautilus. The cosmopolitan interest of the Society is marked by the fact that from 1908 until 1939 the number of corresponding members exceeded that of ordinary members. Nevertheless, the pulse of the Society has always centred in the meetings in London, which have mostly been held in the Linnean Society's rooms, though for a year (1928-29) the Society met in University College, and since 1939 many meetings have been held in the British Museum (Natural History).

The Society has always had good service from its officers, some of whom have served for long periods : J. H. Ponsonby was treasurer from 1900 until 1916 ; the present treasurer, Dr. R. L. Cox. was elected in: 1926 and since 1939 has also served as acting secretary vice Captain G. I. Crawford, absent on war service ; A. E. Salisbury (president 1933-36) served as secretary from 1919 until 1933 ; B. B. Woodward (president 1907-10) and E. A. Smith (president 1901-04) between them edited the Proceedings from 1893 until 1925, the former for periods of eleven and nine years and the latter for twelve years.

One object in founding the Society was to bring: palæontologists into touch with workers on recent Mollusca. A similar motive brought into being the Société malacologique de Belgique, the Annales of which contain far more fossil than recent work. Fossil Mollusca figure largely in the Society's Proceedings; one may instance the many papers by R. Bullen Newton (president 1910-13) and by G. C. Crick on cephalopods, notably two on the pro-ostracum and arms of belemnites. ${ }^{1}$. More recently, a series of papers from 1925 onwards by A. Wrigley on English Eocene and Oligocene gastropods illustrates the value of co-ordinating recent and fossil studies, while Dr. L. R. Cox has contributed many papers on Tertiary and Mesozoic shells, notably a study of the rudist genus Trechmanella ${ }^{2}$. Much of the work on British Pliocene and post-Pliocene non-marine Mollusca by A. S. Kennard and B. B. Woodward appeared in vols. 2-24 of the Proceedings. The close though informal association of the Society with the British Museum indicated by the above names was remarked upon by Dr. A. T. Hopwood in his presidential address to the jubilee meeting, and emphasized by Dr. C. Forster-Cooper in his reply.

Mr. R. Winckworth (president 1939-42) exhibited the Malacological and Conchological Magazine, produced by G. B. Sowerby in 1838 and 1839 with the object of inducing "noblemen and gentlomen" to found a society: he also gave some statistics of the Proceedings of the Malacological Society, now in its twenty-fifth volume and totalling 8,054 pages.

Anatomy very properly holds an important place in the Proceedings. The first paper read and published was on the anatomy of Paryphanta by H. H. Godwin-Austen (president 1897-99), who contributed so largely to our knowledge of Indian land Mollusca. M. F. Woodward, son of H. Woodward, had already written some important anatomical papers before his death in an accident at Ballynakill at the age of thirty-six : his most important work, that on I leurotomaria, was published elsewhere ${ }^{3}$. S. Pace, R. H. Burne, H. A. Pilsbry, H. Watson, N. H. Odhner, H. H. Bloomer and many others have added to this subject in the Proceedings, the last important paper being one by K. M. White on the pericardium and 
pericardial gland in lamellibranchs ${ }^{4}$. The radula has naturally received much attention, especially from A. H. Cooke (president 1913-16) and A. J. Peile (president 1925-27). Molluscan fæoes, a subject initiated by H. B. Moore, which yielded valuable results in systematics as well as in the study of submarine deposits, form the subject of a survey by him twelve years ago ${ }^{5}$.

Many pages naturally are devoted to the description of new forms, such as the papers on British Museum material by E. A. Smith and the long series of papers by J. C. Melvill (president 1929) on shells from the Persian Gulf and Gulf of Oman dredged during 18901914 by Captain F. W. Townsend, who contributed his own reminiscences on collecting ${ }^{6}$.

On the British non-marine Mollusca there are at least three important systematic monographs, that of A. S. Kennard, A. E. Salisbury and B. B. Woodward on Unionidæ ${ }^{7}$, of H. E. Quick on Succinea and A. E. Ellis on Pisidium ${ }^{9}$. A. E. Boycott, the most revered of presidents $(1927-29)$, and that great naturalist, C. Oldham, have given papers on ecology and genetics. Boycott's great work on the inheritance of sinistrality in Limnæa involving a million individuals was published by the Royal Society ${ }^{10}$; a subsidiary investigation on abnormal forms ${ }^{11}$ figures inter alia a snail so equally poised between dextral and sinistral that its shell was a simple cone.

The size of the Proceedings does not often permit long papers. There are, however, some catalogues for which the Society has waived its usual practice, that of Columbellidæ ${ }^{12}$ by S. Pace, of Marginellid $æ^{13}$ and of Conus ${ }^{14}$, both by J. R. le B. Tomlin, and the revision of British nudibranchs by $\mathrm{T}$. Iredale and C. H. O'Donoghue ${ }^{15}$. Much of F. A. Schilder's work on cowries was published by the Society, including the prodrome of a monograph of the Cypræidæ ${ }^{18}$, "perhaps the first attempt to apply on a large scale to marine animals . . methods of geographical delimitation of races"17.

C. D. Sherborn's work on the "Index Animalium" directed the attention of naturalists to the importance of the bibliography of natural history. From 1901 onwards many bibliographical papers appear, the last being one by A. S. Kennard on the Histoire and Prodrome of Férussac ${ }^{18}$. The subject now has its own society and journal.

Exhibits have always been an interesting feature at the meetings and their records are often of interest; for example, W. G. Ridewood's exhibit of Phœnicurus $^{19}$, a genus which proves to be based on the cerata of a nudibranch. A year after Röntgen's discovery in 1895 of X-rays, a series of 'skiagraphs' of shells and living molluses was exhibited ${ }^{20}$; the published plate of a nautilus must. be counted an incunabulum of X-ray photography. Recently X-rays have been used to confirm the systematic relations of the rare shell Thatcheria ${ }^{21}$.

At the jubilee meeting Prof. C. M. Yonge surveyed fifty years' work on functional anatomy, referring especially to the study of the molluscan gill, ciliary feeding, musculature, innervation.

Mr. A. Blok gave an account of shells and ornament, accompanied by a big range of exhibits from savage ornaments to modern industry, touching on ethnological and artistic aspects. Art at its lowest was seen in some of the Victorian 'horrors' and 'rubbish for tourists', while the highest level was shown in some of the cameos exhibited : the best known cameo artist was Benedetto Pistrucci, who also designed the George and dragon of our gold mintage.
Dr. L. R. Cox concluded the jubilee addresses with a review of fifty years of molluscan palæontology.

Honorary membership was instituted in 1921 when Dr. Woodward, the first president, Dr. Paul Pelsenier and Dr. C. D. Sherborn were elected. Since then, apart from previous members of the Society, J. W. Taylor, founder of the Journal of Conchology and of the Conchological Society, Prof. D. M. S. Watson and Sir D'Arey Thompson have been added. Dr. H. A. Pilsbry, who recently celebrated his eightieth birthday, was elected an honorary member at the jubilee meeting.

In $1926 \mathrm{Mr}$. H. McClelland generously presented every member of the Society with a general index to the fifteen volumes of Proceedings and sixteen volumes of the Journal of Conchology, which he had prepared and published. The history of the Conchological Society has been recorded by Dr. J. W. Jackson'22. Percy Edward Radley (1861-1927), a keen amateur of conchology and microscopy, bequeathed his library to the Society. This is kept in the library of University College, London.

In France, malacology has been represented chiefly by the Journal de Conchyliologie, founded by S. Petit de la Saussaye in 1850 and since 1860 associated with the Fischer family. In 1935 the direction of the Journal organized a Réunion amicale of conchologists, malacologists and palæontologists, at which Mr. A. Blok represented the Society. It was resolved to hold triennial meetings in Paris, Brussels and London, but subsequent events have prevented the fulfilment of this plan, which it is hoped will be revived after the War.

${ }^{1}$ Proc. Malac. Soc., 2, 117 (1896) and 7, 269 (1907).

2 Proc. Malac. Soc., 21, 42 (1934).

Quar. J. Micro. Sci., 44, 215 (1901).

4 Reviewed in NATuRE, 150, 771 (1942).

- Proc. Malac. Soc., 19, 281 (1931).

'Proc. Malac. Soc., 19, 281 (1931).

? Proc. Malac. Soc., 16, 267 (1925) and 17, 191 (1927).

s Proc. Malac. Soc., 20, 295 (1933) and 21, 96 (1934).

- Proc. Malac. Soc., 24, 44 (1940).

${ }^{10}$ Boycott, Diver, Garstang, Hardy and Turner, Phil. Trans., B, 219, $51(1930)$

11 Proc. Malac. Soc., 19, 141 (1930).

12 Proc. Malac. Soc., 5, 36 (1902).

${ }_{13}$ Proc. Malac. Soc., 12, 242 (1917) and 13, 41 (1918).

14 Proc. Malac. Soc., 22, 205 (1937).

15 Proc. Malac. Soc., 15, 195 (1923).

${ }^{16}$ Proc. Malac. Soc., 23, 119 (1938-39).

17 NATURE, 144,642 (1939)

18 Proc. Malac. Soc., 25, 12 and 105 (1942).

10 Proc. Malac. Soc., 8, 121 (1908).

so Proc. Malac. Soc., 2, pl. 15, 179, 205 (1897).

${ }^{21}$ Eales, Proc. Malac. Soc., 23, 15 (1938).

$22 J$. Conchol., 18, 65 (1927).

\section{OBITUARIES}

\section{Dr. Leopold Frommer}

Dr. Leopold Frommer, of High Duty Alloys, Ltd., died after an operation on January 27, at the age of fifty. $\mathrm{He}$ was born of Polish parents and obtained his diploma in mechanical engineering at the Technical University of Berlin (Charlottenburg).

I first met Dr. Frommer in 1929, when he was working under Prof. M. Polanyi at the Kaiser Wilhelm Institut für Physikalische- und Elektrochemie, in Dahlem, Berlin. He had just given up what promised to be a very successful industrial engineering career in order to take up fundamental research on the study of chemical kinetics. My interest was aroused, however, by his great knowledge of the pressure die-casting technique and his ability to apply funda- 